\title{
Turning waste into value: potassium-promoted Red Mud as an effective catalyst for the hydrogenation of $\mathrm{CO}_{2}$
}

\author{
Artem Russkikha, Genrikh Shterk ${ }^{a}$, Bandar H. Al-Solami ${ }^{b}$, Bandar A. Fadhel ${ }^{b}$, Adrian Ramirez ${ }^{a}$, and \\ Jorge Gascon*,a
}

\begin{abstract}
Since 1887 Red Mud is an unavoidable waste derived from the production of alumina in the Bayer process. Because of its high alkalinity and metal loading, Red Mud disposal and storage constitute an important environmental risk. With worldwide storage capacity reaching its limits and no alternatives to the Bayer Process, the development of methods for the valorization of Red Mud is a must. Here, we demonstrate that Red Mud can be turned into an efficient catalyst for the valorization of $\mathrm{CO}_{2}$. By a simple potassium promotion, $45 \%$ conversion of $\mathrm{CO}_{2}$ with a light olefin $\left(\mathrm{C}_{2}-\mathrm{C}_{4}\right)$ selectivity of $36 \%$ has been achieved at $375^{\circ} \mathrm{C}, 30$ bar and at $9600 \mathrm{~mL} \cdot \mathrm{g}^{-1} \cdot \mathrm{h}^{-1}$, matching the performance of some of the best catalysts reported to date.
\end{abstract}

\section{Introduction}

With the constant world population growth (expected to reach 8.6 billion in 2030, 9.8 billion in 2050 and 11.2 billion in $2100^{[1]}$ ), waste management has become one of the biggest challenges of our society. The storage of industrial hazardous wastes is considered particularly challenging by the scientific community. Among them, Red Mud is one of the most critical, being already the cause of severe ecological accidents. ${ }^{[2]}$ This waste is generated during alumina production in the Bayer process, responsible for more than $95 \%$ of all alumina produced in the world. In this process, for one ton of aluminum oxide produced 0.3 to 2.5 tons of residues are co-generated. ${ }^{[3]}$ As a consequence, 155 million tons of Red Mud are being created annually ${ }^{[4]}$ with worldwide storage capacity already exceeded over 3.5 billion tons in 2014. ${ }^{[5]}$ The typical disposal and storage methods for Red Mud are marine, lagooning, dry stacking and dry cake disposal. ${ }^{[6]}$ However, Red Mud solutions are highly alkaline ( $\mathrm{pH}$ range from 10 to 13 ), have a considerable metal content and, therefore, the potential leach into the soil represents a real danger for our environment. ${ }^{[7]}$

Nevertheless, the presence of different metals in Red Mud could potentially allow its use as a catalyst. In this line of research several attempts have been made by the scientific community, ${ }^{[8,}$ 9] but still no real application of Red Mud has been found. Among all possible applications, $\mathrm{CO}_{2}$ valorization, only when carried out

[a] A. Russkikh, G. Shterk, A. Ramirez, J. Gascon. KAUST Catalysis Center (KCC), Advanced Catalytic Materials. King Abdullah University of Science and Technology (KAUST). Thuwal 23955, Saudi Arabia.

E-mail: jorge.gascon@kaust.edu.sa

[b] Bandar H. Al-Solami, Bandar A. Fadhel.

Carbon Management Research Division, Research \& Development

Center. Saudi Aramco, Dhahran, Saudi Arabia. with renewable hydrogen, ${ }^{[10]}$ could present a turning point as two wastes $\left(\mathrm{CO}_{2}\right.$ and Red Mud) could be valorized at the same time making use of renewable energy. Mostly two different thermocatalytic routes have been proposed to convert $\mathrm{CO}_{2}$ into highly demanded products ${ }^{[11-13]}$ : (i) it can be hydrogenated into methanol that can be further converted to olefins or aromatics over a zeolite in a bifunctional configuration, ${ }^{[14,15]}$ or, (ii) it can be converted over an Fe catalyst via reverse water gas shift (RWGS) to $\mathrm{CO}$ and $\mathrm{H}_{2}$ which will be further converted into a variety of hydrocarbons following a typical Fischer-Tropsch synthesis (FTS) mechanism. ${ }^{[15]}$ The main advantage of the $\mathrm{Fe}$ route is the low undesired $\mathrm{CO}$ selectivity coupled with the large range of hydrocarbons. ${ }^{[16]}$ Catalysts promoted with potassium which increase selectivity to light olefins are especially interesting. ${ }^{[17]}$ Moreover, light olefins market is expected to reach 475.8 million USD at the end of 2027 , with an annual growth rate of $5.85 \% .{ }^{[18]}$ Here, we demonstrate that, via potassium promotion, Red Mud can be turned into an efficient catalyst for the valorization of $\mathrm{CO}_{2}$ achieving a $45 \%$ conversion of $\mathrm{CO}_{2}$ with a light olefin $\left(\mathrm{C}_{2}-\mathrm{C}_{4}\right)$ selectivity of $36 \%$ at $375{ }^{\circ} \mathrm{C}, 30$ bar and at $9600 \mathrm{~mL} \cdot \mathrm{g}^{-1} \cdot \mathrm{h}^{-1}$ matching the performance of some of the best catalysts reported to date.

\section{Results and Discussion}

\section{$\underline{\text { Red Mud characterization }}$}

We first performed X-ray Fluorescence (XRF) analysis to investigate the elemental composition of our Red Mud sample, as the composition can vary depending on the country of origin. ${ }^{[9]}$ Our results show that the Red Mud employed in this study contains $14.3 \%$ of $\mathrm{Na}, 15.0 \%$ of $\mathrm{Al}, 15.5 \%$ of $\mathrm{Si}, 0.8 \%$ of $\mathrm{S}, 0.1 \%$ of $\mathrm{K}, 2.1 \%$ of $\mathrm{Ca}, 3.6 \%$ of $\mathrm{Ti}$ and $6.4 \%$ of $\mathrm{Fe}$. However, analysis of different areas shows a great heterogeneity within the sample (spectra of 4 different measurements can be found in supplementary information, Figure S1), being in range with the reported typical compositions. ${ }^{[4]}$ The high iron content confirms that, indeed, Red Mud can be a real catalyst candidate for the hydrogenation of $\mathrm{CO}_{2}$. Additionally, the presence of $\mathrm{Na}$ and traces of $\mathrm{K}$ can be beneficial for olefin production. ${ }^{[19]}$ Moreover, Ti can potentially improve catalytic performance of $\mathrm{Fe}$ in the FTS synthesis. ${ }^{[20]}$ Finally, the high content of $\mathrm{Al}$ in the sample shows the limitation of the Bayer process, with almost $17 \%$ of aluminum left unrefined.

Scanning Electron Microscopy (SEM) revealed highly roughened particles of 50 to $200 \mu \mathrm{m}$ in size (see Figure S2). The elemental distribution of these particles shows certain agreement with the 
XRF characterization, pointing out again the heterogeneity of the sample (see Table S1). A better picture of the Red Mud composition can be observed by performing elemental mappings (see Figure 1), where several segregated phases can be distinguished: one containing $\mathrm{Na}, \mathrm{Si}$ and $\mathrm{Al}$, one containing $\mathrm{Fe}$ and one containing Ti. Oxygen is well distributed across whole particle. In accordance with the EDS-SEM data, X-ray Diffraction Spectroscopy (XRD) revealed several crystalline phases: Gibbsite $\left(\mathrm{Al}(\mathrm{OH})_{3}\right)$, Perovskite $\left(\mathrm{CaTiO}_{3}\right)$, Hematite $\left(\mathrm{Fe}_{2} \mathrm{O}_{3}\right)$ and Cancrinite (hydrate of carbonate and silicate of sodium, calcium and aluminum) (see Figure 2).
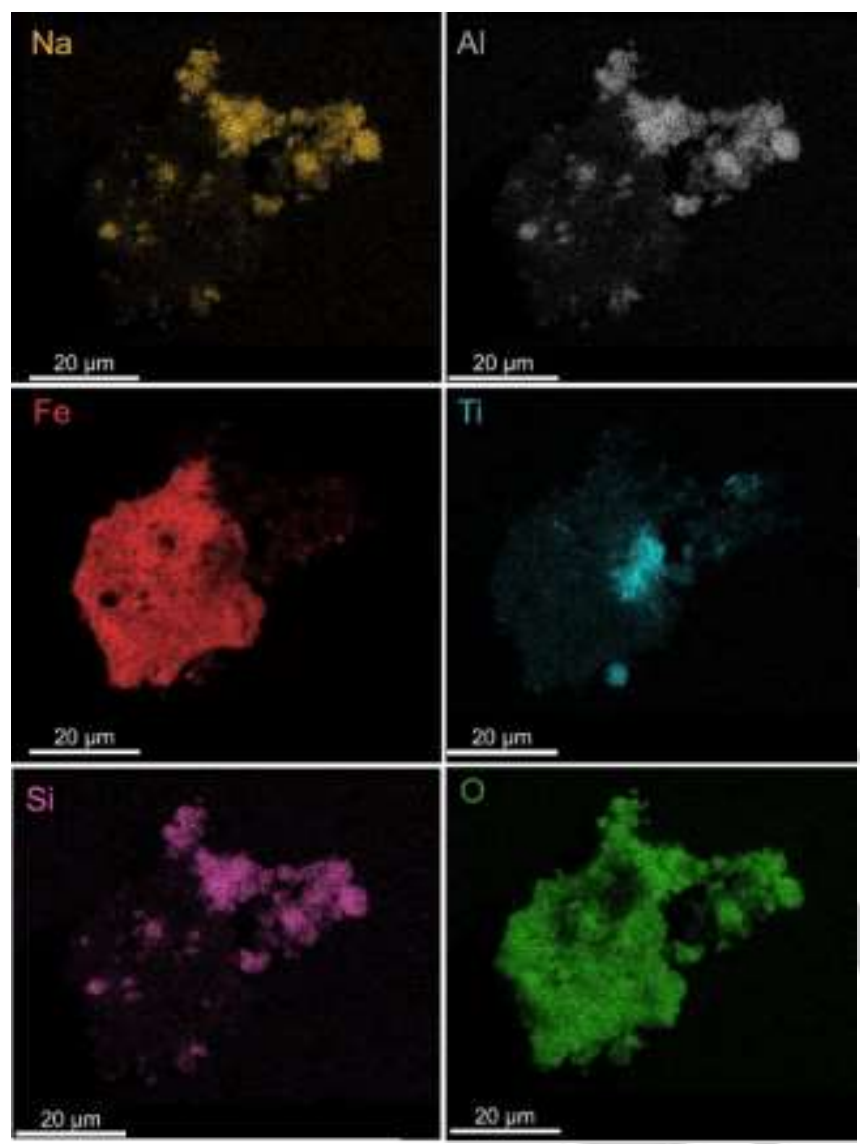

Figure 1. Elemental EDS-SEM mapping of a Red Mud particle.

Transmission Electron Microscopy (TEM) showed the presence of particles with different sizes from around 10 to $80 \mathrm{~nm}$ and agglomerates with sizes from $500 \mathrm{~nm}$ to several $\mu \mathrm{m}$ (see Figure S4). Nitrogen physisorption at $77 \mathrm{~K}$ of Red Mud revealed a type $\mathrm{V}$ isotherm with $\mathrm{H} 3$ hysteresis ${ }^{[21]}$ (see Figure S5). The BET area of the Red Mud studied was $12 \mathrm{~m}^{2} \cdot \mathrm{g}^{-1}$, in line with other Red Mud measurements. ${ }^{[2]}$

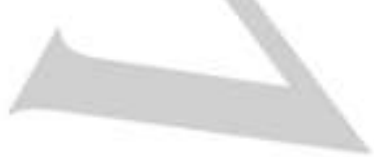

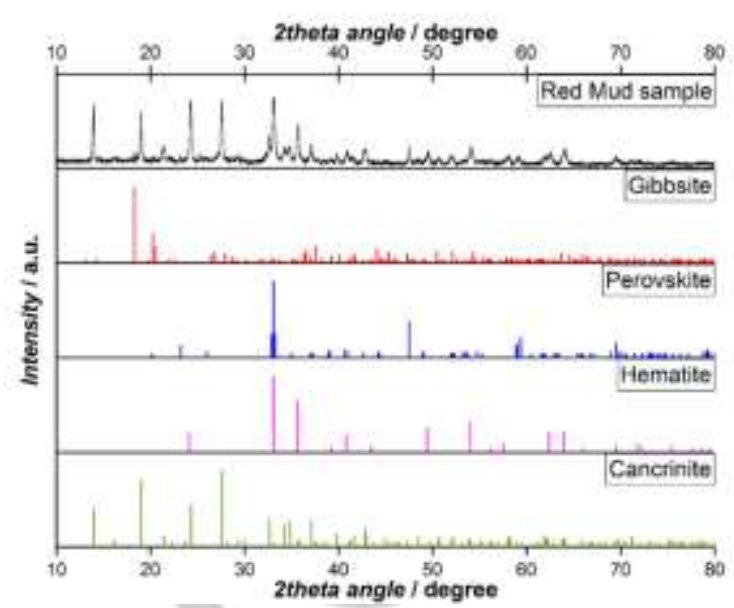

Figure 2. XRD spectra of Red Mud and simulated diffractograms of Gibbsite, Perovskite, Hematite and Cancrinite (PDF 04-011-1369, PDF 04-007-5451, PDF 01-089-0596 and PDF 01-075-8617 correspondingly).

\section{Red Mud as catalyst for the hydrogenation of $\mathrm{CO}_{2}$}

The catalytic performance of Red Mud and Red Mud promoted with $\mathrm{K}$ can be found on Figure 3. We can observe that, as expected from the above characterization, the unpromoted Red Mud is active in the hydrogenation of $\mathrm{CO}_{2}$ at all the temperatures studied (see Figure $3 \mathrm{a}$ ), specially at relatively high temperatures: under the studied reaction conditions (30 bar, $\left.9600 \mathrm{~mL} \cdot \mathrm{g}^{-1} \cdot \mathrm{h}^{-1}\right)$ raising the reaction temperature from 325 to $375^{\circ} \mathrm{C}$ increased the conversion of $\mathrm{CO}_{2}$ from $25 \%$ to $42 \%$ and the selectivity to $\mathrm{C}_{2}-\mathrm{C}_{4}$ olefins from $4 \%$ to $15 \%$. This performance was stable during for at least $50 \mathrm{~h}$.

As it is already known for this reaction, promotion with $K$ drastically enhances the selectivity to olefins (see Figure $3 b$ ) by favoring $\mathrm{CO}_{2}$ adsorption and decreasing the hydrogenation strength of $\mathrm{Fe} .{ }^{[23]}$ After promotion, selectivity to light olefins increases up to $36 \%$ at $350{ }^{\circ} \mathrm{C}$ and even higher conversions are achieved (up to $45 \%$ at $375{ }^{\circ} \mathrm{C}$ ) while catalyst stability remains unchanged. The selectivity to $\mathrm{CO}$ for the unpromoted Red Mud decreases with increasing the reactor temperature (from $30 \%$ at $325^{\circ} \mathrm{C}$ to $16 \%$ at $375^{\circ} \mathrm{C}$, see Figure S6). On the other hand, for the $\mathrm{K}$ promoted samples, similar values are obtained regardless of the temperature (circa 20-25\%). This behavior is in line with our previous observations ${ }^{[23]}$ : when $\mathrm{K}$ promoted, temperature has little effect in the overall $\mathrm{CO}$ selectivity.

We further evaluated the effect of $\mathrm{K}$ loading (see Figure 3c). After 28 hours on stream, at nearly isoconversion, selectivity to $\mathrm{C}_{2}-\mathrm{C}_{4}$ olefins increases from $15 \%$ for the unpromoted sample to $22 \%$, $30 \%$ and $36 \%$ for samples containing $0.5,1.0$ and 2.0 wt $\% \mathrm{~K}$ correspondingly. In addition, increasing the $\mathrm{K}$ content also leads to an increase of the formation of higher hydrocarbons $\left(\mathrm{C}_{5_{+}}\right)$. This phenomena is also observed by the increasing of alpha from 0.42 to 0.57 (see Figure S7). ${ }^{[24]}$ Again, this behavior is in line with our previous observations ${ }^{[23]}$ : increasing the $\mathrm{K}$ content will lead to a decrease in the hydrogenation activity of $\mathrm{Fe}$ and therefore to the preference formation of olefins that may re-adsorb and allow 
further chain growth. ${ }^{[25]}$ The detailed product distribution of the $K$ promoted and unpromoted samples can be found on Figure $3 \mathrm{~d}$. Finally, we also investigated the effect of the type of $\mathrm{K}$ precursor by comparing $\mathrm{KOH}$ and $\mathrm{K}_{2} \mathrm{CO}_{3}$ as its source. Our data show that the performance of both precursors is very similar, with $\mathrm{K}_{2} \mathrm{CO}_{3}$ showing a slightly better $\mathrm{C}_{2}-\mathrm{C}_{4}$ olefins selectivity at the same conversion level (see Figure S8).

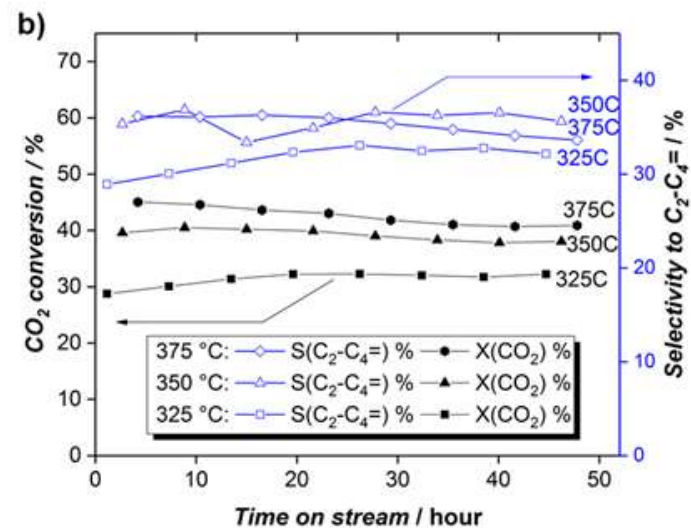

d)

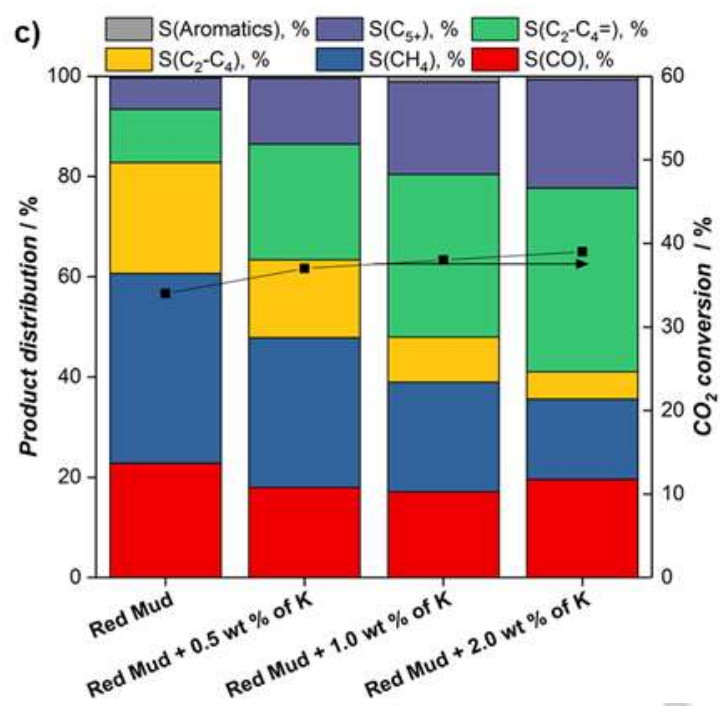

a)

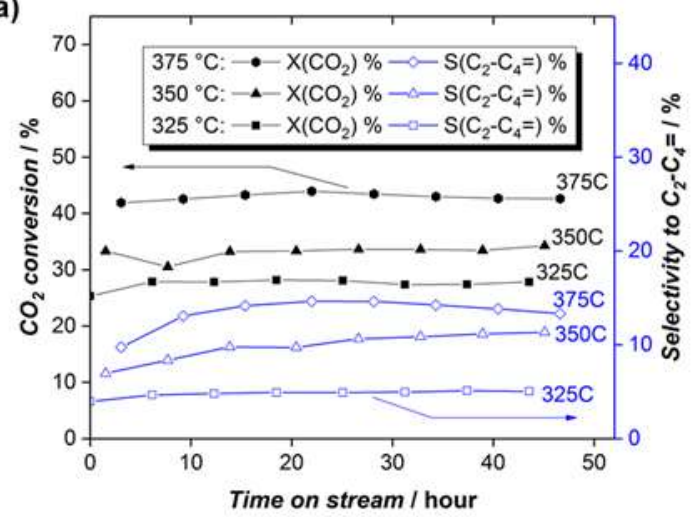

$\square$ co $\square$ Parafins $\square$ Olefins $\square$ Aromatics

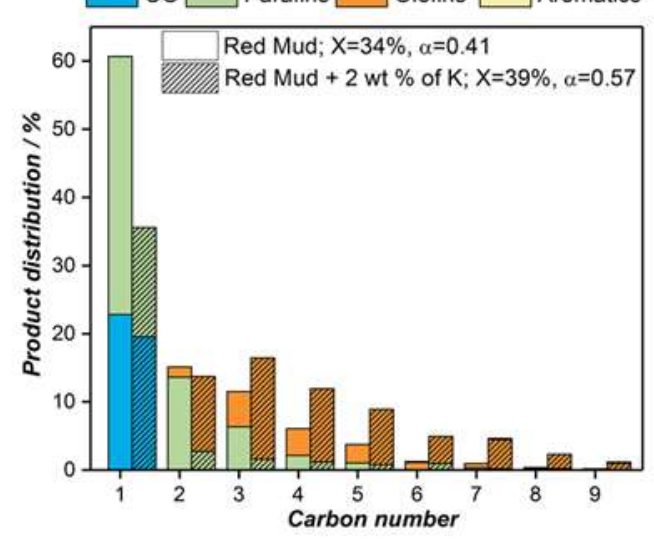

Figure 3. Catalytic results of Red Mud and $\mathrm{K}$ promoted Red Mud in the hydrogenation of $\mathrm{CO}_{2}$. a) $\mathrm{CO}_{2}$ conversion and selectivity to $\mathrm{C}_{2}-\mathrm{C}_{4}$ olefins at $325{ }^{\circ} \mathrm{C}$, $350{ }^{\circ} \mathrm{C}$ and $375{ }^{\circ} \mathrm{C}$ for Red Mud; b) $\mathrm{CO}_{2}$ conversion and selectivity to $\mathrm{C}_{2}-\mathrm{C}_{4}$ olefins at $325^{\circ} \mathrm{C}, 350{ }^{\circ} \mathrm{C}$ and $375{ }^{\circ} \mathrm{C}$ for Red Mud promoted with 2 wt $\%$ of $\mathrm{K}$ from $\mathrm{K}_{2} \mathrm{CO}{ }_{3}$; c) Product distribution for Red Mud and Red Mud promoted with $\mathrm{K}$ from $\mathrm{K}_{2} \mathrm{CO}_{3}$ after $28 \mathrm{~h} \mathrm{TOS}$; d) Detailed product distribution of the Red Mud and Red Mud promoted with 2 wt $\%$ of $\mathrm{K}$ from $\mathrm{K}_{2} \mathrm{CO}_{3}$ after $25 \mathrm{~h}$ TOS. Reaction conditions: $350{ }^{\circ} \mathrm{C}$, 30 bar, $\mathrm{CO}_{2}: \mathrm{H}_{2}=1: 3$, and $9600 \mathrm{~mL} \cdot \mathrm{g}^{-1} \cdot \mathrm{h}^{-1}$.

XRD after reaction revealed that iron partially reduces under reaction conditions (from Fe $\mathrm{Fe}^{\mathrm{III}}$ to $\mathrm{Fe}$ ", see Figure 4a). This reduction is accompanied with decreasing of peak intensities related to Hematite and increasing the ones related to Magnetite. If we look in detail at the 30 to $502 \theta$ degree region, we can observe that iron carbide is formed during the reaction ${ }^{[26]}$ (see Figure 4b). Finally, no significant differences were found in the phase distribution by comparing spectra of samples with and without $\mathrm{K}$ promotion. Comparison of XPS spectra before and after reaction points out the same direction (see Figure 4c): the content of iron carbide increases after reaction for both samples. In addition, Red Mud samples contain a variety of different iron compounds, such as $\mathrm{Fe}_{3} \mathrm{C}, \mathrm{Fe}_{2} \mathrm{O}_{3}, \mathrm{FeO}, \mathrm{K}_{2} \mathrm{FeO}_{4}$, and metallic
$\mathrm{Fe}^{[27-30]}$ (Table S3). Similarly to the XRD, K promotion does not change the distribution of iron species according to XPS.Similarly to the $\mathrm{XRD}, \mathrm{K}$ promotion does not change the distribution of iron species according to XPS.

TGA-MS analysis of the spent and fresh catalyst samples is shown in Figure S9. Comparison among catalysts before and after reaction reveals differences that are associated to the chemical change in the structure of the catalyst upon reaction conditions and that discard the formation of coke, that would normally be identified by an overlap between $\mathrm{H}_{2} \mathrm{O}$ and $\mathrm{CO}_{2}$ (18 and 44 mass-to-charge ratio). For fresh samples, evolution of water is obvious between 200 and $500^{\circ} \mathrm{C}$ and can be attributed to the decomposition of Gibbsite ${ }^{[31]}$, phase absent after reaction, as 
observed by XRD analysis. In case of the fresh promoted Red Mud, evolution of $\mathrm{CO}_{2}$ and $\mathrm{H}_{2} \mathrm{O}$ at $120^{\circ} \mathrm{C}$ is associated with the decomposition of $\mathrm{KHCO}_{3}$. The evolution of $\mathrm{CO}_{2}$ in spent samples, together with the absence of considerable amounts of $\mathrm{H}_{2} \mathrm{O}$ is associated to the oxidation of iron carbide, which is more abundant in case of promoted samples.

Following, TPR was performed on Red Mud and 2 wt \% with $\mathrm{K}$ promoted Red Mud (see Figure S10). Several differences could be observed upon comparing both samples: (i) peaks below $120{ }^{\circ} \mathrm{C}$ for $\mathrm{K}$ promoted sample, which arise from the decomposition of $\mathrm{KHCO}_{3}$ that starts at $67^{\circ} \mathrm{C}^{[32]}$; (ii) peaks in the region from $\sim 370{ }^{\circ} \mathrm{C}$ to $\sim 730{ }^{\circ} \mathrm{C}$, which come from the reduction of iron species: reduction of Hematite $\left(\mathrm{Fe}_{2} \mathrm{O}_{3}\right)$ into Magnetite $\left(\mathrm{Fe}_{3} \mathrm{O}_{4}\right)$ at $420^{\circ} \mathrm{C}$ (vs. $450{ }^{\circ} \mathrm{C}$ for the promoted sample), broad reduction of Magnetite to iron monoxide from $510^{\circ} \mathrm{C}$ to $720^{\circ} \mathrm{C}$ (vs. from $530{ }^{\circ} \mathrm{C}$ to $730{ }^{\circ} \mathrm{C}$ for the promoted sample); after that, the reduction to metallic $\mathrm{Fe}$ at $750{ }^{\circ} \mathrm{C} \cdot{ }^{[33-35]}$ In line with the literature, the addition of $\mathrm{K}$ shifts reduction temperature of iron oxide species to higher temperatures. ${ }^{\left[{ }^{[6]}\right.}$ Unlike the metallic phase, these iron oxides are the active species for the RWGS reaction. ${ }^{24]}$ Furthermore, these oxides are reactants for the carbide formation, which is the selective phase for the hydrocarbon synthesis via FT. Next, the basicity and $\mathrm{CO}_{2}$ adsorption behavior of the different catalysts was studied by $\mathrm{CO}_{2}$ and $\mathrm{H}_{2}$ TPD. As expected, $\mathrm{CO}_{2}$ TPD of promoted and unpromoted Red Mud revealed that potassium incorporation leads to an increase of the $\mathrm{CO}_{2}$ adsorbed ${ }^{[23]}$ (see Figure S11). The two peaks observed can be attributed to moderately $\left(200-500^{\circ} \mathrm{C}\right)$ and strong basic sites $\left(500-800{ }^{\circ} \mathrm{C}\right) .{ }^{[37]}$ It is worth noting that the unprompted Red Mud shows already the presence of basic sites derived from the presence of $\mathrm{Na}$ and $\mathrm{Ca}$ in the material. The $\mathrm{H}_{2}$ TPD showed two main peaks at around $430^{\circ} \mathrm{C}$ and $490^{\circ} \mathrm{C}^{[38]}$ with a noticeable signal decrease for the $\mathrm{K}$ promoted sample. These results are in line with our previous observations of potassium promotion reducing $\mathrm{H}_{2}$ adsorption ${ }^{[23]}$. Altogether, we can conclude that during reaction the selective carbide phase formation takes place and that, in line with previous works, the main $\mathrm{K}$ role is likely to be that of an electronic modulator.

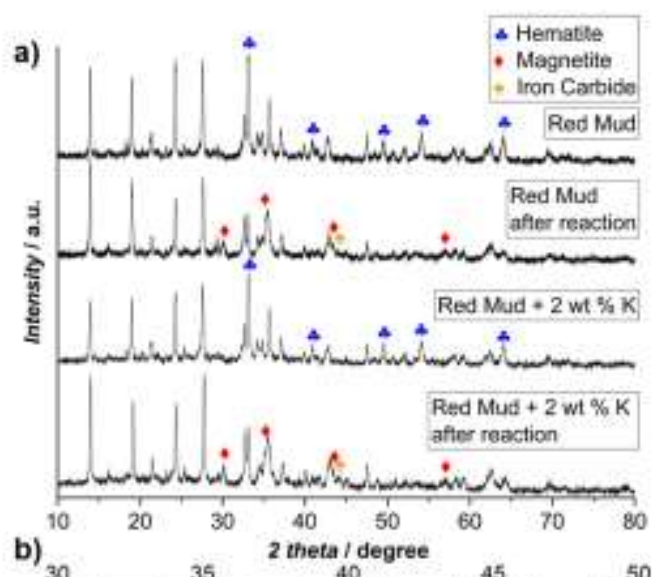

c)

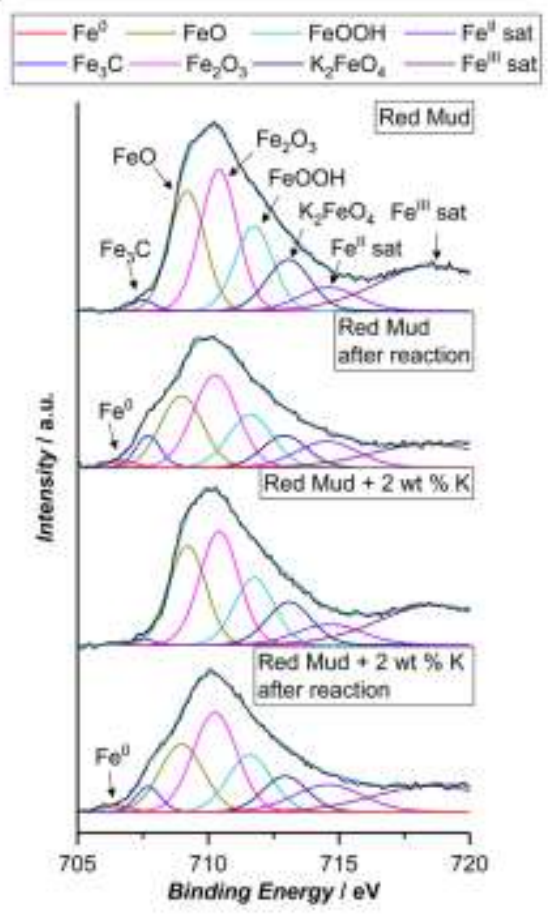

Figure 4. Characterization of Red Mud and Red Mud promoted with $2 \%$ of $\mathrm{K}$ after reaction at $350{ }^{\circ} \mathrm{C}, 30$ bar and 50 hours TOS a) XRD results of iron containing phases of samples before and after catalytic reaction (PDF 01-089-0596, PDF 04-012-7038, PDF 04-014-4562 diffractograms were used for Hematite, Magnetite and iron carbide phases correspondingly); b) 30 to $502 \theta$ degree region of samples before and after catalytic reaction; c) XPS analysis results of samples before and after catalytic reaction. 
Last but not least, if we compare the data reported in this work with the state of the art iron-based catalysts published for this application ${ }^{[23,26,39-54]}$ (see Table S4), we can observe that Red Mud outperforms most of them and only our recent Fe MOFmediated catalyst ${ }^{[23]}$ displays a higher space time yield into olefins

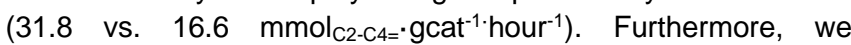
compared the Red Mud sample with commercially available iron (III) oxide (see experimental section and Table S5). Our results show that both catalysts display similar performance, although Red Mud sample is slightly superior. Nevertheless, this simple catalyst made by commercial iron oxide is still superior to most of catalysts of Table S4. These critical observations highlight the importance of rational design when developing complex (and expensive) supported $\mathrm{CO}_{2}$ to olefins catalysts: iron waste or even plain iron oxide are likely to be superior by just a simple potassium promotion.

\section{Conclusions}

In summary, Red Mud seems a very promising candidate for the conversion of $\mathrm{CO}_{2}$ to olefins. By a simple potassium promotion, $45 \%$ conversion of $\mathrm{CO}_{2}$ with a light olefin $\left(\mathrm{C}_{2}-\mathrm{C}_{4}\right)$ selectivity of $36 \%$ has been achieved at $375^{\circ} \mathrm{C}, 30$ bar and at $9600 \mathrm{~mL} \cdot \mathrm{g}^{-1} \cdot \mathrm{h}^{-1}$, matching the performance of some of the best catalysts reported to date. We hope that these results will motivate the scientific community to take a step further in the valorization of industrial waste in catalytic applications.

\section{Experimental Section}

Red Mud was kindly provided by Saudi Aramco. Samples with 0.5, 1.0, 2.0 wt $\%$ of $\mathrm{K}$ were prepared by suspension in $\mathrm{K}_{2} \mathrm{CO}_{3}$ (Aldrich, $99.9 \%$ ) or $\mathrm{KOH}$ (Aldrich, 99.9\%) solutions. The amount of added water was minimal for making a suspension of Red Mud. In a typical synthesis, $170 \mathrm{mg}$ of Red Mud and the appropriate amount of $\mathrm{K}$ precursor were mixed in $0.7 \mathrm{~mL}$ of deionized $\mathrm{H}_{2} \mathrm{O}$ in a $25 \mathrm{~mL}$ round-bottom flask. Then, the flask with the solution was connected to a rotatory evaporator at $90 \mathrm{rpm}$ rate under 200 mbar pressure and $70{ }^{\circ} \mathrm{C}$ for 60 minutes. After evaporation, samples were dried in the oven using a heating rate of $5{ }^{\circ} \mathrm{C} \cdot \mathrm{min}^{-1}$ until $100{ }^{\circ} \mathrm{C}$ and held at this temperature for $12 \mathrm{~h}$. Iron (III) oxide nanopowder ( $<50 \mathrm{~nm}$ particle size, Aldrich) was used for comparison purposes. $\mathrm{K}$ promotion was done in a similar way as in the Red Mud samples.

X-ray Fluorescence (XRF) analysis was performed on a Horiba $\AA^{\mathrm{X}} \mathrm{XGT}$ 7200. The X-ray tube is equipped with a $R$ target, voltage was set at 30 $\mathrm{kV}$, no X-ray filter was used, and analysis preset time was $400 \mathrm{~s}$. Before measurement, samples were placed on a double-sided tape (NICETACK ${ }^{\mathrm{TM}}$, Prod. No NW-15) and then put into the chamber, which was then degassed. An average of four measurements per sample were taken.

Scanning Electron Microscopy (SEM) was performed on a FEI® Teneo VS microscope in the optiplan mode using the Everhart-Thornley detector. Samples were placed on a double-sided carbon tape (PELCO Tabs ${ }^{\mathrm{TM}}$, Prod. No 16084-1) on the aluminum stub prior to SEM characterization. No additional coating was applied. Distance between beam gun and sample was maintained at $10 \mathrm{~mm}$. Accelerating voltage and beam current were set to $5 \mathrm{kV}$ and $50 \mathrm{pA}$ correspondingly. Energy-Dispersive X-ray
Spectroscopy (EDS) analysis was done by using a TEAM ${ }^{\mathrm{TM}}$ EDS analysis system provided by EDAX® at 20 or $30 \mathrm{kV}$ and 3.2 or $13 \mathrm{nA}$ current. Distance between beam gun and sample was $10 \mathrm{~mm}$. Samples' drift was less than $2 \%$ during EDS sessions. Dead time was in the $30-40 \%$ range.

X-ray Diffraction Spectroscopy (XRD) was performed on a Brucker® D8 Advance. The source of $\mathrm{X}$-ray radiation was $\mathrm{CuKa}$ and the analysis was performed in a $2 \theta$ range from 10 to $80^{\circ}$. X-ray voltage was set to $40 \mathrm{kV}$, current was $40 \mathrm{~mA}$. The crystalline phase was identified by comparison with Powder Diffraction File ${ }^{\mathrm{TM}}(\mathrm{PDF} \otimes)$, from the International Center for Diffraction Data. Elimination of fluorescence and $\mathrm{K} \beta$ radiation was done by using a LYNXEYE XE-T detector.

Transmission Electron Microscopy (TEM) was conducted on a FEI® Tecnai Twin microscope in the bright field mode. Prior to study, samples were grinded and sonicated in ethanol, then $2 \mu \mathrm{L}$ of its solution was put on the carbon film (Electron Microscopy Sciences ${ }^{\circledR}$, Prod. FCF400-CU). Filament voltage was set to $120 \mathrm{kV}$.

Nitrogen physisorption at $77 \mathrm{~K}$ study was conducted on a Micrometrics $\AA^{\circledR}$ ASAP 2420 analysis system. Samples were degassed to $67 \mathrm{~Pa}$ at 1330 $\mathrm{Pa} \cdot \mathrm{s}^{-1}$ rate, then hold for $60 \mathrm{~min}$. Following, a temperature ramp was performed at $10{ }^{\circ} \mathrm{C} \cdot \mathrm{min}^{-1}$ rate until $300{ }^{\circ} \mathrm{C}$, then held for $12 \mathrm{~h}$. The $\mathrm{N}_{2}$ adsorption isotherm was measured between $p \cdot\left(p^{0}\right)^{-1}=0.01-0.95$. BET surface area was calculated between $p$ to $p^{0}$ ratio in $0.05-0.30$ range.

Catalytic tests were conducted in a 16 channel Flowrence $\AA$ Avantium setup. The reactors are standard steel with an inner diameter of $2.3 \mathrm{~mm}$. Typically, $50 \mathrm{mg}$ of catalyst were placed per reactor. The reaction feed had $72 \%$ of $\mathrm{H}_{2}, 24 \%$ of $\mathrm{CO}_{2}$ and $4 \%$ of $\mathrm{He}$ as a standard. The ratio between gas flow and mass of catalyst was maintained at $9600 \mathrm{~mL} \cdot \mathrm{g}^{-1} \cdot \mathrm{h}^{-1}$ pe channel. One of the 16th channels was used without catalyst as a blank. The reaction was studied at $325^{\circ} \mathrm{C}, 350^{\circ} \mathrm{C}$ and $375^{\circ} \mathrm{C}$, while the pressure was maintained at 30 bar. Prior to feeding the reaction mixture all samples were pretreated in situ with a pure $\mathrm{H}_{2}$ atmosphere for 4 hours at $350{ }^{\circ} \mathrm{C}$ and 3 bar. After that, the tubes were pressurized using a membrane-based pressure controller. $\mathrm{CO}_{2}$ conversion $(\mathrm{X}, \%)$, selectivity $(\mathrm{S}, \%)$, and space time yields (STY, mmol.gcat ${ }^{-1} \cdot \mathrm{h}^{-1}$ ) were calculated using the following formulas:

$$
\begin{gathered}
X\left(\mathrm{CO}_{2}\right)=\left(1-\frac{C\left(\mathrm{He}_{\text {blank }}\right) \cdot C\left(C \mathrm{O}_{2}\right)}{C\left(\mathrm{He}_{R}\right) \cdot C\left(C \mathrm{CO}_{2 \text { blank }}\right)}\right) \cdot 100 \\
S\left(C_{n}\right)=\frac{n \cdot C\left(C_{n}\right)}{\sum_{x}\left(n \cdot C\left(C_{n}\right)\right)} \cdot 100 \\
\operatorname{STY}\left(C_{n}\right)=\frac{X\left(C O_{2}\right) \cdot S\left(C_{n}\right) \cdot S V \cdot 0.24}{22.4} \cdot \frac{1}{10000}
\end{gathered}
$$

where $C\left(\mathrm{He}_{\text {blank }}\right), \mathrm{C}\left(\mathrm{CO}_{2 \mathrm{R}}\right), \mathrm{C}\left(\mathrm{He}_{\mathrm{R}}\right), \mathrm{C}\left(\mathrm{CO}_{2 b l a n k}\right)$ are the concentrations of the $\mathrm{He}$ in the blank reactor, $\mathrm{CO}_{2}$ in the outlet of the reactor, $\mathrm{He}$ in the outlet of the reactor and $\mathrm{CO}_{2}$ in the blank one determined by $\mathrm{GC}$ analysis respectively; $C\left(C_{n}\right)$ is the concentration of the product with $n$ carbon atoms in the reactor outlet determined by GC analysis, $x$ is the total number of all analyzed products; $S V$ is the space velocity calculated in $\mathrm{mL} \cdot \mathrm{gcat}^{-1} \cdot \mathrm{h}^{-1}$, and 0.24 is the $\mathrm{CO}_{2}$ molar concentration in the blank reactor. Gas Chromatograph is an Agilent 7890B with two sample loops. One sample loop goes to Thermal Conductivity Detector (TCD) channel with 2 Haysep pre-column and MS5A, where $\mathrm{He}, \mathrm{H}_{2}, \mathrm{CH}_{4}$ and $\mathrm{CO}$ are separated. Another sample loop goes to an Innowax pre-column ( $5 \mathrm{~m}, 0.20 \mathrm{MM}$ OD, $0.4 \mathrm{uM}$ film), first $0.5 \mathrm{~min}$ of the method the gases coming from pre-column are sent to Gaspro column (Gaspro 30M, 0.32 MM OD) followed by Flame Ionization Detector (FID). Gaspro column separates $\mathrm{C}_{1}-\mathrm{C}_{8}$, parafins and olefins. After $0.5 \mathrm{~min}$, valve is switched and gases are sent to Innowax column ( $45 \mathrm{~m}, 0.2 \mathrm{MM}$ OD, $0.4 \mathrm{uM}$ ) followed by FID. Innowax separates oxygenates, larger paraffins and olefins $\left(>C_{9}\right)$ and aromatics BTX and $\mathrm{C}_{9_{+}}$ 
aromatics. The front FID also has the possibility for $\mathrm{CO}$ and $\mathrm{CO}_{2}$ measurement after $\mathrm{CO}$ and $\mathrm{CO}_{2}$ is converted to $\mathrm{CH}_{4}$ with a $\mathrm{Ni}$ based methanizer. The error found in carbon balance was smaller than $2.5 \%$. Oxygenates selectivity was lower than $0.5 \%$ in all samples.

The surface chemical composition of the powder samples was analyzed using high resolution X-ray Photoelectron Spectroscopy (XPS) on a Kratos Axis Ultra DLD spectrometer equipped with a monochromatic AlKa X-ray source $(\mathrm{hv}=1486.71 \mathrm{eV})$ operating at $150 \mathrm{~W}$, under ultra-high vacuum $\left(\sim 10^{-9}\right.$ mbar). Measurements were taken in hybrid mode using electrostatic lenses, and the take-off angle was $0^{\circ}$. All spectra were recorded using an aperture slot of $300 \times 700 \mu \mathrm{m}$. The survey and highresolution spectra were collected at fixed analyzer pass energies of 160 $\mathrm{eV}$ and $20 \mathrm{eV}$ respectively. For charge neutralization source of the low energy electrons was applied. As a reference for spectrum calibration, the $\mathrm{C} 1 \mathrm{~s}$ peak with binding energy $285.0 \mathrm{eV}$ was used. The data was analyzed using commercially available software, CasaXPS v.2.3.19.

Thermal Gravimetric Analysis (TGA) coupled with Mass Spectroscopy (MS) was performed on Mettler Toledo® TGA/DSC 1 STARe System and ThermoStar ${ }^{\mathrm{TM}}$ GSD 320 T3 correspondingly. $10 \mathrm{mg}$ of sample were placed into $70 \mu \mathrm{L}$ alumina crucible. Then, sample was heated in $30 \mathrm{~mL} \cdot \mathrm{min}^{-1} \mathrm{flow}$ of air with $10^{\circ} \mathrm{C} \cdot \mathrm{min}^{-1}$ rate from $40^{\circ} \mathrm{C}$ to $800^{\circ} \mathrm{C}$. The gases were analyzed on the Faraday detector in Multiple lon Detection mode.

Temperature-Programmed Reduction (TPR) was performed on a Micrometrics $\AA$ Autochem 2920 setup. $50 \mathrm{mg}$ of sample were placed in the U-shaped quartz reactor between two layers of quartzwool. Following, 50 $\mathrm{mL} \cdot \mathrm{min}^{-1}$ of $\mathrm{He}$ flow were introduced for $15 \mathrm{~min}$. Then, flow was changed to $50 \mathrm{~mL} \cdot \mathrm{min}^{-1}$ of $10 \% \mathrm{H}_{2}$ in Ar. Sample was afterwards heated with $5{ }^{\circ} \mathrm{C} \cdot \mathrm{min}^{-1}$ temperature rate until $800{ }^{\circ} \mathrm{C}$. Analysis of exhaust gases was performed on a TCD.

Temperature-Programmed Desorption (TPD) of $\mathrm{H}_{2}$ and $\mathrm{CO}_{2}$ was performed on Altamira Instruments ${ }^{\circledR}$ AMI-200 IP setup. $200 \mathrm{mg}$ of sample were placed in the U-shaped quartz reactor between two layers of quartzwool. First, $40 \mathrm{~mL} \cdot \mathrm{min}^{-1}$ of $\mathrm{Ar}$ flow were introduced for $5 \mathrm{~min}$. Following, flow was changed to $32 \mathrm{~mL} \cdot \mathrm{min}^{-1}$ of pure $\mathrm{H}_{2}$ for 20 minutes. Next, sample was heated with $5^{\circ} \mathrm{C} \cdot \mathrm{min}^{-1}$ rate until $350^{\circ} \mathrm{C}$, and held at this temperature 4 hours under the $\mathrm{H}_{2}$ flow. Afterwards, the sampled was cooled down in $40 \mathrm{~mL} \cdot \mathrm{min}^{-1}$ of $\mathrm{Ar}$ to $50^{\circ} \mathrm{C}$ and held at this temperature for 2 hours. For adsorption of $\mathrm{CO}_{2}$ or $\mathrm{H}_{2} 40 \mathrm{~mL} \cdot \mathrm{min}^{-1}$ flow of pure $\mathrm{H}_{2}$ or $25 \%$ $\mathrm{CO}_{2}$ in $\mathrm{He}$ were introduced into the reactor at $50{ }^{\circ} \mathrm{C}$ for 2 hours. Then, 40 $\mathrm{mL} \cdot \mathrm{min}^{-1}$ of $\mathrm{Ar}$ flow were fed for 60 minutes at to get rid of unadsorbed species. Finally, desorption was studied with $5^{\circ} \mathrm{C} \cdot \mathrm{min}^{-1}$ heating rate until $800{ }^{\circ} \mathrm{C}$. Analysis of gases was performed on a TCD with Ar using as a reference gas.

\section{Acknowledgements}

Funding for this work was provided by King Abdullah University of Science and Technology (KAUST).

Keywords: Heterogeneous catalysis $•$ Waste chemistry $・$ Red $\mathrm{Mud} \cdot \mathrm{CO}_{2}$ conversion $\cdot$ Olefins

[1] United Nations, Vol. Volume I: Comprehensive Tables, New York, 2017, p. 346.

[2] D. Winkler, A. Bidló, B. Bolodár-Varga, Á. Erdő, A. Horváth, Sci. Total Environ. 2018, 644, 1292-1303.
[3] International Aluminium Institute, European Aluminium Association, 2015, p. 31

[4] International Aluminium Institute, European Aluminium Association, 2018, p. 56

[5] S. Xue, F. Zhu, X. Kong, C. Wu, L. Huang, N. Huang, W. Hartley, Environ. Sci. Pollut. Res. 2016, 23, 1120-1132.

[6] G. Power, M. Gräfe, C. Klauber, Hydrometallurgy 2011, 108, 33-45.

[7] S. Ruyters, J. Mertens, E. Vassilieva, B. Dehandschutter, A. Poffijn, E. Smolders, Environ. Sci. Technol. 2011, 45, 1616-1622.

[8] B. Qiu, N. Deng, Y. Zhang, H. Wan, Asia-Pac. J. Chem. Eng. 2018, 13 e2150.

[9] S. Sushil, V. S. Batra, Appl. Catal., B 2008, 81, 64-77.

[10] G. Glenk, S. Reichelstein, Nat. Energy 2019, 4, 216-222.

[11] H. Yang, C. Zhang, P. Gao, H. Wang, X. Li, L. Zhong, W. Wei, Y. Sun Catal. Sci. Technol. 2017, 7, 4580-4598.

[12] A. Álvarez, A. Bansode, A. Urakawa, A. V. Bavykina, T. A. Wezendonk M. Makkee, J. Gascon, F. Kapteijn, Chem. Rev. 2017, 117, 9804-9838.

[13] C. F. Shih, T. Zhang, J. Li, C. Bai, Joule 2018, 2, 1925-1949.

[14] Z. Ma, M. D. Porosoff, ACS Catal. 2019, 9, 2639-2656.

[15] A. Dokania, A. Ramirez, A. Bavykina, J. Gascon, ACS Energy Lett. 2019 4, 167-176.

[16] T. Riedel, H. Schulz, G. Schaub, K.-W. Jun, J.-S. Hwang, K.-W. Lee, Top. Catal. 2003, 26, 41-54.

[17] D. L. King, J. B. Peri, J. Catal. 1983, 79, 164-175.

[18] Kenneth Research, (Ed.: D. Dooley), 2019.

[19] H. Yang, C. Zhang, P. Gao, H. Wang, X. Li, L. Zhong, W. Wei, Y. Sun Catalysis Science \& Technology 2017, 7, 4580-4598.

[20] V. P. Santos, L. Borges, S. Sartipi, B. Van der Linden, A. I. Dugulan, A Chojecki, T. Davidian, M. Ruitenbeek, G. R. Meima, F. Kapteijn, M. Makkee, J. Gascon, Appl. Catal., A 2017, 533, 38-48.

[21] M. Thommes, K. Kaneko, V. Neimark Alexander, P. Olivier James, F. Rodriguez-Reinoso, J. Rouquerol, S. W. Sing Kenneth, in Pure Appl. Chem., Vol. 87, 2015, p. 1051

[22] M. Gräfe, C. Klauber, Hydrometallurgy 2011, 108, 46-59.

[23] A. Ramirez, L. Gevers, A. Bavykina, S. Ould-Chikh, J. Gascon, ACS Catal. 2018, 8, 9174-9182.

[24] G. P. Van Der Laan, A. A. C. M. Beenackers, Catal. Rev.: Sci. Eng. 1999 41, 255-318.

[25] V. P. Santos, T. A. Wezendonk, J. J. D. Jaén, A. I. Dugulan, M. A Nasalevich, H.-U. Islam, A. Chojecki, S. Sartipi, X. Sun, A. A. Hakeem, A. C. J. Koeken, M. Ruitenbeek, T. Davidian, G. R. Meima, G. Sankar, F. Kapteijn, M. Makkee, J. Gascon, Nat. Commun. 2015, 6, 6451.

[26] A. Ramirez, S. Ould-Chikh, L. Gevers, A. D. Chowdhury, E. Abou-Hamad A. Aguilar-Tapia, J.-L. Hazemann, N. Wehbe, A. J. Al Abdulghani, S. M Kozlov, L. Cavallo, J. Gascon, ChemCatChem 2019, 11, 2879-2886.

[27] C. Myers, H. Franzen, J. Anderegg, Inorg. Chem. 1985, 24, 1822-1824.

[28] I. N. Shabanova, V. A. Trapeznikov, J. Electron Spectrosc. Relat. Phenom. 1975, 6, 297-307.

[29] N. S. Mclntyre, D. G. Zetaruk, Anal. Chem. 1977, 49, 1521-1529.

[30] H. Konno, M. Nagayama, J. Electron Spectrosc. Relat. Phenom. 1980 18, 341-343.

[31] J. T. Kloprogge, H. D. Ruan, R. L. Frost, J. Mater. Sci. 2002, 37, 1121 1129

[32] M. Hartman, K. Svoboda, B. Čech, M. Pohořelý, M. Šyc, Ind. Eng. Chem Res. 2019, 58, 2868-2881.

[33] R. C. C. Costa, F. C. C. Moura, P. E. F. Oliveira, F. Magalhães, J. D. Ardisson, R. M. Lago, Chemosphere 2010, 78, 1116-1120.

[34] S. F. Kurtoğlu, A. Uzun, Sci. Rep. 2016, 6, 32279.

[35] S. Ordóñez, H. Sastre, F. V. Díez, Appl. Catal., B 2001, 29, 263-273.

[36] S. C. Ndlela, B. H. J. I. Shanks, e. c. research, Ind. Eng. Chem. Res. 2003, 42, 2112-2121.

[37] W. Cai, Q. Chen, F. Wang, Z. Li, H. Yu, S. Zhang, L. Cui, C. Li, Catal. Lett. 2019, 149, 2508-2518.

[38] L. Huazhang, L. Caibo, L. Xiaonian, C. Yaqing, Ind. Eng. Chem. Res. 2003, 42, 1347-1349. 
[39] F. Ding, A. Zhang, M. Liu, Y. Zuo, K. Li, X. Guo, C. Song, Ind. Eng. Chem. Res. 2014, 53, 17563-17569.

[40] S. Hu, M. Liu, F. Ding, C. Song, G. Zhang, X. Guo, J. $\mathrm{CO}_{2}$ Util. 2016, 15, 89-95.

[41] C. G. Visconti, M. Martinelli, L. Falbo, A. Infantes-Molina, L. Lietti, P. Forzatti, G. laquaniello, E. Palo, B. Picutti, F. Brignoli, Appl. Catal., B 2017, 200, 530-542.

[42] S.-S. Nam, S.-J. Lee, H. Kim, K.-W. Jun, M.-J. Choi, K.-W. Lee, Energy Convers. Manage. 1997, 38, S397-S402.

[43] M. Albrecht, U. Rodemerck, M. Schneider, M. Bröring, D. Baabe, E. V. Kondratenko, Appl. Catal., B 2017, 204, 119-126.

[44] J. Liu, A. Zhang, M. Liu, S. Hu, F. Ding, C. Song, X. Guo, J. $\mathrm{CO}_{2}$ Util. 2017, 21, 100-107.

[45] J. Liu, Y. Sun, X. Jiang, A. Zhang, C. Song, X. Guo, J. $\mathrm{CO}_{2}$ Util. 2018, 25, $120-127$

[46] Z. You, W. Deng, Q. Zhang, Y. Wang, Chin. J. Catal. 2013, 34, 956-963.

[47] Y. H. Choi, Y. J. Jang, H. Park, W. Y. Kim, Y. H. Lee, S. H. Choi, J. S. Lee, Appl. Catal., B 2017, 202, 605-610.

[48] P. H. Choi, K.-W. Jun, S.-J. Lee, M.-J. Choi, K.-W. Lee, Catal. Lett. 1996, 40, 115-118.

[49] L. M. Chew, P. Kangvansura, H. Ruland, H. J. Schulte, C. Somsen, W. Xia, G. Eggeler, A. Worayingyong, M. Muhler, Appl. Catal., A 2014, 482, 163-170.

[50] S.-S. Nam, H. Kim, G. Kishan, M.-J. Choi, K.-W. Lee, Appl. Catal., A 1999, 179, 155-163.

[51] J. Wei, J. Sun, Z. Wen, C. Fang, Q. Ge, H. Xu, Catal. Sci. Technol. 2016 6, 4786-4793.

[52] W. Wang, X. Jiang, X. Wang, C. Song, Ind. Eng. Chem. Res. 2018, 57, 4535-4542.

[53] T. Numpilai, N. Chanlek, Y. Poo-Arporn, S. Wannapaiboon, C. K. Cheng, N. Siri-Nguan, T. Sornchamni, P. Kongkachuichay, M. Chareonpanich, G. Rupprechter, J. Limtrakul, T. Witoon, Appl. Surf. Sci. 2019, 483, 581 592.

[54] J. Liu, A. Zhang, X. Jiang, G. Zhang, Y. Sun, M. Liu, F. Ding, C. Song, X. Guo, Ind. Eng. Chem. Res. 2019, 58, 4017-4023.

[55] I. T. Burke, W. M. Mayes, C. L. Peacock, A. P. Brown, A. P. Jarvis, K. Gruiz, Environ. Sci. Technol. 2012, 46, 3085-3092.

[56] J. F. Moulder, J. Chastain, Handbook of X-ray Photoelectron Spectroscopy: A Reference Book of Standard Spectra for Identification and Interpretation of XPS Data, Physical Electronics Division, PerkinElmer Corporation, 1992. 


\section{WILEY-VCH}

\section{FULL PAPER}

\section{Table of Contents}

\section{FULL PAPER}

Red Mud can be turned into an efficient catalyst for the valorization of $\mathrm{CO}_{2}$ into hydrocarbons. By a simple potassium promotion, high selectivity to $\mathrm{C}_{2}-\mathrm{C}_{4}$ olefins can be achieved at high conversion levels. With a stable catalyst operation, red mud matches the performance of some of the best catalysts reported to date.

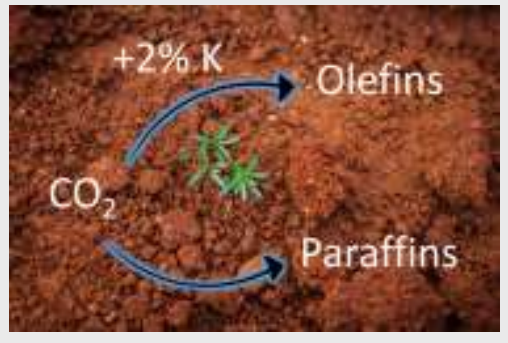

Artem Russkikh, Genrikh Shterk, Bandar H. Al-Solami, Bandar A. Fadhel, Adrian Ramirez, and Jorge Gascon*

\section{Page No. - Page No.}

Turning waste into value: potassiumpromoted Red Mud as an effective catalyst for the valorization of $\mathrm{CO}_{2}$ 